\title{
THE DEVELOPMENT OF A MEASURING INSTRUMENT FOR ASSESSING A HIGH PERFORMANCE CULTURE
}

\author{
W VAN HEERDEN \\ G ROODT \\ groodt@uj.ac.za \\ Department of Human Resources Management \\ University of Johannesburg
}

\begin{abstract}
The objective of this study was firstly, to develop an integrated theoretical model of a high performance organisational culture and secondly, to develop a measuring instrument based on the said model for assessing such a culture. The questionnaire was administered to a sampling frame of 600 employees of a manufacturing company that employs about 3500 people. 313 Completed questionnaires (response rate 52\%) were returned and used for the analyses. First level factor analyses were conducted on the item inter-correlation matrices of the 12 theoretical dimensions. A second level factor analysis on the sub-score inter-correlation matrix resulted in a single factor being extracted. Iterative item analyses yielded sound metric properties for each dimension and a Cronbach Alpha of 0,947 for the scale. The findings of further analyses are discussed.
\end{abstract}

Key words

High performance culture, performance excellence, high performance organisation

Since 1994, the South African markets have been characterised by a range of comprehensive changes of which the opening of the local markets to global competition was perhaps the most challenging. Leadership in organisations found themselves having to change their thinking and align themselves to a global mindset. Besides being challenged by the global economy, organisations also had to face increased customer demands and diversity, shareholder expectations, e-business and increased competition by rival businesses (Clemmer, 2005; Darling, 1999). Only a few companies found that they had the experience and the skills to effectively compete in a multinational or a global market.

In order to counter these challenges many corporations opted for operating their businesses under leaner structures within a framework of reduced costs, but with a view of increased productivity. According to Darling (1999), this approach was feasible, but only to a point, and had only resulted in marginal gains being achieved by these organisations. The ability to satisfy customers and employees has gained increasing attention as "the competition for both market share and people has become stiffened and the ability to measure employee and customer satisfaction especially has received increasing attention" (Dahlgaard, Kristensen \& Kanji, 1998 cited in Eskildsen, Juhl \& Kristensen, 2001, p. 785). According to Neely (1999), these non-financial indicators are forcing businesses to change their strategies and performance measures to stay competitive.

The focus of many local companies for the last decade has been to grow their capabilities and skills and to develop a high performance culture. These capabilities and skills supported by a high-performance culture would enable companies to compare their actual performance with the best in their class and to continually search for ways to even further improve their performance. This is re-iterated by Eygelaar $(2004$, p. 8) who states that "regardless of the type of organisation or the size of the organisation, to strive for excellence, an organisation must be able to measure its performance." This can only be achieved if companies have cultivated what is known as a "high performance culture'.

\section{Defining a High Performance Culture}

Different interpretations exist in the explanation of a high performance culture. In an attempt to source a definition of a high performance culture, it was found that a high performance culture could be described in many ways and that each literature source offered its own perspective. One perspective is that high performance culture could be understood as an extension of organisational culture. McNamara (1999) compares organisational culture to that of an individual's personality comprising of a set of assumptions, norms, values and signs (artefacts) which can be seen in the organisations' members and their behaviours. In a similar way, the way a person dresses, speaks and behaves is a reflection of their personality and their behaviour is influenced by their own set of assumptions, values, beliefs and norms (McNamara, 1999). Some writers hold the view that an organisation's culture influences the way people think consciously and subconsciously, the way they make decisions and extends to the way they feel and behave (Hansen \& Wernerfelt, 1989; Schein, 1990 cited in Lok \& Crawford, 2004). It has been argued that this kind of influence could have considerable impact on organisations in terms of their performance (Deal \& Kennedy, 1982; Peters \& Waterman, 1982 cited in Lok \& Crawford, 2003).

Further review of the collection of literature, revealed that to assign an exact definition to the concept of high performance culture was a challenge. In turn, the authors found that the terms High Performance Culture or High Performance Organisations, World-Class Organisations and Organisational Performance Excellence were used interchangeably in the literature studied. Clemmer (2005) asserts that high performance organisations integrate the intangible elements of their character (that which give meaning to the people in the organisation) with the tangible elements (the organisation's management processes and systems). These tangible elements are said to translate the ideals of the organisation into action (Clemmer, 2005). Eygelaar (2004) conceptualises organisational performance excellence as a goal which is based on the organisation's corporate culture, values and belief systems which are underlined by an integrated framework and strategic determinants. The strategic determinants form the foundation upon which organisations are able to build their competitiveness (Eygelaar, 2004, p. xx). For the purpose of the paper, high performance culture or organisational performance excellence as posited by Eygelaar (2004) was viewed as the most appropriate definition.

The cultural aspect of the definition was seen to relate to an organisation's character, where the collective behaviour patterns of its members is an indication of the way things are typically done in an organisation (Bower, 1966; Quinn, 1988). The underlying framework and strategic determinants were the 
elements that created the character. One method of extracting the key elements of a particular framework is made possible through culture measurement.

Culture measurements can be classified as subjective or objective. Subjective culture measurement entails indirect assessment of an organisation using instruments that assess subjective perceptions of organisational members. Objective culture measurement involves the direct assessment of the organisation that is not based on any theoretical explanations (Payne \& Pugh, 1976), but rather "on a more visible level the behaviour patterns or style of an organisation" (Kotter \& Heskett, 1992, p. 4)(Also compare White, 1991). This paper focuses on the objective approach where the characteristics or features of the organisation are commonly visible and observable.

It was apparent from the literature evaluation that different streams of thought existed on performance excellence and high performance culture and the observable characteristics that identify them. The schools of thought are discussed further with reference to selected exemplary models.

\section{Exemplary models on performance excellence}

Excellence models

It has become accepted international practice that excellence models provide the key to organisations that seek to enhance their high performance work practices and levels of performance excellence.

Excellence models provide companies with the ability to compare (benchmark) themselves with other similar organisations and to recognise the crucial areas of their business that require improvement (Eygelaar, 2004). Some of the major excellence awards, each based on its own model of excellence, established during the latter part of the twentieth century for Japan, USA and Europe are the Deming Award, the Malcolm Baldridge National Quality Award (MBNQA) and the European Foundation for Quality Management (EFQM) Award.

The Deming Award was introduced in Japan in the 1950s following the work done by W. Edwards Deming in the field of quality management. The main focus of the award revolves around the quality and dependability of products (Neely, 1999). It also focuses on addressing factors which impact on the management of facilities, vendors, procurement and service within the organisation. In addition, the MBNQA and EFQM awards focus on the impact that the organisation has on society, their people, partnerships, resources and customers. The value of the Deming Award is that it focuses on awarding organisations that use world-class processes and procedures to produce high quality and reliable commodities. The MBNQA and EFQM recognises that the success of a business is not only based on highly effective internal processes and procedures but also on how effective the business has responded according to the needs of the customer, the employee and the community. Eygelaar (2004) summarises that the scope of the two latter awards is broader than the Deming Award, but has less depth.

Within the South African context, the South African Excellence Model (SAEM, 2000) with its roots based in the MBNQA and EFQM models was developed on the following premise (summarised by the authors):

An organisation's level of performance is measured by its impact on society, customer and people satisfaction as well as supplier and partnership performance. The level of excellence is determined by the effectiveness of the company's processes supported by its policies and strategy, customer and market focus, people management, resource and information management which is driven by its leadership. The common elements that are revealed by the models discussed above allude to the fact that organisational performance excellence or high performance organisations are driven by strong leadership that ensure excellence is achieved through effective management of the enablers of the organisation. These enablers include the strategies, policies and procedures, systems and processes as well as resources of the business. The organisation is evaluated against not only financial results but also by its impact on the customer and broader society. These models suggest that high performance culture contains the elements of strong leadership, operate within a framework of policies and procedure and manage their resources effectively. Notwithstanding that the emphasis on the customer, the employee and the community is explicit.

The elements of the SAEM are depicted in Figure 1 below:

\section{The Balanced Scorecard}

It is well known that organisations have always been concerned with measuring their performance even when performance, in most cases, was based on a single bottom line. Since business is a multifaceted concept, it is not surprising that researchers had to question the flaws linked to traditional accounting systems (Zhao, 2004; Neely, 1999). Performance measurement practices or the more widely used self-assessment practices have thus evolved in the past few decades in response to the multifaceted nature of the business world.

Self-assessment is an evaluation process which involves the assessment of an organisation's activities and results weighted against a business excellence benchmark (SAEM, 2000). Regular evaluations allow the organisation to identify areas of strength as well as identifying gaps in its business. The results

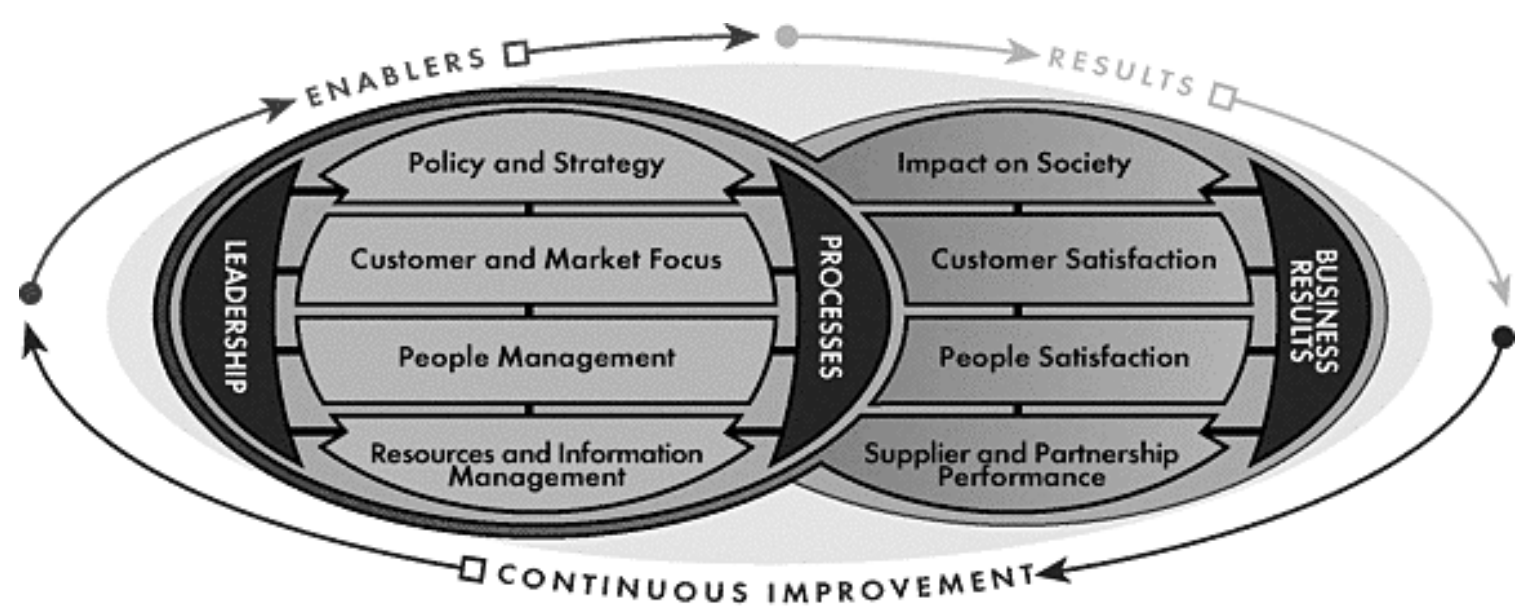

Figure 1: The South African Excellence Model (sourced from www.saef.co.za, Feb 2006) 
of the evaluation enables the organisation to develop action plans to improve on the disparities identified and use the plans to monitor their progress (Samuelsson \& Nilsson, 2002). For Samuelsson and Nilsson (2002, p. 11), a further benefit of self-assessment for organisations, is that "it encourages an ethos of continuous improvement, promotes a holistic perspective and allows people to gain a broader understanding of the business."

An example of an instrument of self-assessment is the balanced scorecard (Kaplan \& Norton, 1996). The scorecard was introduced, as a response by companies, to counter the limitations that were posed by traditional accounting measures. The scorecard ensures that the company's vision and strategy is translated into operational execution which effectively can be measured from four perspectives namely, a financial, an internal process, a customer as well as an innovation and learning perspective (Kaplan \& Norton, 1996). The financial dimension typically measures the organisation's operating profit and return on investment (the tangible outcomes) whilst the internal process looks at the operating, customer management, regulatory and social processes that deliver according to the customer's expectations as well as ways of improving quality and productivity (Kaplan, 2005). The customer dimension measures customer satisfaction, retention and growth. This dimension influences how the organisation aligns its future strategy to ensure increased revenue that is linked to the customer value proposition (Kaplan, 2005). The fourth dimension of innovation and learning evaluates the intangible assets required to support the strategy. These include establishing who the right people are, the systems and processes as well as organisational climate required to effectively support the business strategy (Kaplan, 2005). In comparison, the popular MBNQA selfassessment measures the group's performance under five categories of customer, financial and market, human resources, supplier and partner performance and organisational effectiveness. For Evans and Jack (2003), the two assessments (the balanced scorecard and the MBNQA) ultimately end up measuring very similar dimensions although their approaches seem to be different.

Similarly, emanating from the SAEM is a self-assessment questionnaire which organisations can use as a diagnostic tool to score their level of excellence against internationally recognised criteria. A search for empirical evidence of the use of the questionnaire revealed that a study had been conducted by Eygelaar (2004) where a customised self-assessment questionnaire, based on the SAEM model, was applied in the military health service. Barring this study, it was not evident to the authors that the assessment had been widely used in South Africa.

Most of the big five consulting firms have also developed organisational surveys however, the surveys assess mostly concepts and models linked to organisational effectiveness and that only contain some elements of what would constitute a high performance culture. These surveys were not focused exclusively on evaluating specific high performance cultural dimensions per sé. Other models of high performance organisations will be covered next.

\section{High performance organisations}

Similar to describing an individual's personality, organisations said to have a high performance culture display certain common attributes or trends. Some of these trends have already been alluded to above. According to Samson and Challis (1999), these trends are observable patterns within the organisation that include: a single integrated strategy aimed at improving the company; a conscious focus to create principles that will guide the management of behaviour in organisations; active management of performance; linking rewards for all employees to the success of the business; benchmarking themselves against other leading competitors and setting new stretch goals.
Nasser and Vivier (1995, p. 12) explain that "many organisations are suffering from the effects of outdated management approaches, a sense of smugness, uncompetitive organisational designs, impoverished leadership, impotent strategic thinking, dated labour practices and organisational instability." These factors, according to them, impede the ability of an organisation to create wealth and sustainability.

Nasser and Vivier (1995) purported that research has shown that new generation organisations (or high performance organisations) share certain distinct characteristics such as visionary thinking, a 'can do' mindset and clear understanding of strategy. These characteristics set the new generation organisation apart from their traditional counterparts.

Nasser and Vivier (1995) undertook a study to assess organisational success by using what they describe as "the single most important factor in judging corporate success, financial performance based on asset and equity growth and returns" (p. 17). The aim of the study was to establish what practices in the various industries, included in the study, characterised long-term sustainable growth. Their study evaluated new generation organisations by way of specific statistical parameters developed by the Bureau of Financial Analysis at the University of Pretoria. They supplemented their findings with substantial subjective information as well. The results emanating from the study were used for the development of ten principles that drive the behaviour of new generation organisations. These principles are contained in the three broader categories of: engaging the market, mobilising capabilities and energising the people.

Nasser and Vivier (1995) developed a model from the statistical results and the subjective information that they had captured in their study. However, the key question, for the authors, remained and that was whether the principles of Nasser and Vivier's model had been empirically tested in the market. The work done by others such as Cowen and Osborne (2002) and Prescott (1998) also established similar principles.

Cowen and Osborne (2002) maintained that high performance organisations have an unmistakable profile that differentiates them from ordinary functional organisations. The characteristics are contained in their distinguishing corporate culture, the people and the management systems. These three categories are briefly described further:

- Corporate Culture

In high performance companies, employees have a clear understanding of what the company wants to achieve and they believe in the vision of the business. They are treated fairly and poor performance is frowned upon while good performance is rewarded. It is a company where employees are committed to long service and also, importantly, organisations with high performance cultures are recognised by their 'vibe' and described as exciting places to be in.

- The People

The people within these organisations believe that anything is possible. They are obsessed on beating their competitors and they are determined to do whatever is required to achieve success. The organisation's recruitment and selection strategies ensure that the best people are appointed. The CEO is an admired and respected figure in the organisation.

- The Management System

High performance companies have a solid strategy. The strategy contains three key elements namely, precise performance measurements; a solid recognition system for great performance as well as clear and transparent communication systems. This ensures that employees always know what is expected of them; the rewards and recognition system has a credible reputation and employees always know what is happening within the organisation. 
Some of the dimensions that were strikingly similar amongst these models were that high performance organisations have visionary ideals which are translated into clear strategy. The employees within the organisation understood the company's vision and strategy. The organisation recognised that getting the right human capital was important hence their recruitment and selection procedures were aligned accordingly. Other policies and procedures such as performance management and reward and recognition structures were also in place.

\section{Customer-centric model}

Many companies have had to redesign their business strategies in response to increasing competition worldwide, where a shift is taking place in society from a product-led market to a consumerled market and many companies now focus their strategies on customer-centred initiatives. Although these organisations consistently pursue excellence, they often fail to align the skill and competence of their employees to their strategy where contemporary strategies are often implemented by outdated management systems (Prescott, 1998).

Prescott (1998) stated that customer-centred organisations understand that to stay ahead in the game, they need to ensure that the needs and expectations of their customers and stakeholders are met or exceeded in relation to what their competitor is able to provide. Similar to Cowen and Osborne (2002), Prescott (1998) described high performance organisations as organisations that are focused on upskilling employees, multi-skilling, building effective teams and retaining key people. The combination of competent, flexible, adaptable and motivated people is the key driving force of the organisation to achieving excellence.

In order to create a high performance culture or world class organisation, Prescott (1998) believed that the ability of an organisation to continuously and effectively measure its performance was a vital component as "performance measures provide both management and employees with standards which focus their attention on what is most important to measure and on how well they are performing" (p. 3).

Prescott developed a model called the customer-centred measurement system (CCMS). The key driver underpinning the model is certainly its customer-centricity but the model is broadly divided into three levels of performance measures which organisations can use to assess their status quo in terms of performance excellence. At the business level, the company relates to its markets and finance indicators to measure its performance. At the centre of the CCMS is the second level which looks at the impact that the company has on the community, the satisfaction level of the customer, employee satisfaction, labour costs, productivity and flexibility. At the operational level, companies are able to measure their effectiveness in terms of their response to environmental and safety standards, the quality of their service delivery and their effectiveness in leveraging on their people resources.

Prescott (1998) placed great emphasis on the fact that the focus of world-class organisations are no longer concentrated on customer satisfaction and productivity but rather, organisational excellence is based on the extent of an organisation's flexibility and responsiveness to the customer's needs as well as the positive impact that the organisation has on the community. The ability of the organisation to customise and quickly respond to customer demands as well as to ensure that it can provide environmentally friendly products and services have become key indicators of high performance organisations.

\section{World-class model}

A model of the world-class organisation that was postulated by Prinsloo, Moropodi, Slabbert and Parker (1999) depicted direction, the delivery process and business results as the three broad categories of their model. Direction as the first category is made up of two main elements namely leadership and customercentred strategy. The central category or the delivery category to the model is composed of what Prinsloo et al. (1999) term as the organisation's fabric. This fabric is characterised by the organisation's capability to operate on lean structures, lean production and processes and leaner use of equipment. Another concept that is referred to in this category is joint governance. According to Prinsloo et al. (1999), joint governance revolves around the partnering relationship between various stakeholders such as the customer, employee, suppliers, organised labour, government and the community. This is a popular concept in businesses today and will increase in importance for South African organisations who seek to ensure sustainability into the future. The last category looks at the final measurement indicators that organisations would use to assess their level of performance excellence. Broadly described, the indicators would include how cost effective the organisation has operated, the level of quality of its service and products, its speed of service delivery, the perceived satisfaction levels of its customers, employees and community. At the end of the spectrum, and one of the most important measurement indicators, is how financially profitable and competitive the organisation is in the market. The Prinsloo et al. (1999) model provides a succinct structural framework for categorising the different elements of a high performance culture into three broad groupings with a clear link between the vision and its execution. This framework will form the template of the integrated theoretical model to be proposed next in this article.

\section{An integrated high performance organisational culture} model

The preceding evaluation was focussed primarily on understanding the meaning of a high performance culture, reviewing a selection of the most prominent models around high performance organisations and performance excellence and examining the evolution of the practice of measuring high performance in the context of the changing world of business. The interest generated by the evaluation was the lack of the existence of a consolidated model on high performance culture which led the authors to develop the following integrated model of a high performance culture. The following integrated model is a theorectial design of a high performance culture:

\section{Direction}

In all of the models discussed, one of the single-most important dimensions that high performing organisations possess is a clear vision and a solid strategy. This dimension is a key determinant required in high performance organisations as it sets direction and provides a platform to design strategic plans and set goals for the sustainability of the company into the future (Cowen \& Osborne, 2002; Marquardt, 1999; Nasser \& Vivier, 1995; Prescott, 1998; Prinsloo et al., 1999; Rhinesmith, 1996; Robson, 1988; Samson \& Challis, 1999).

One of the key drivers of the vision and strategy is the commitment displayed by leadership figures in the organisation (Cowen \& Osborne, 2002; Nasser \& Vivier, 1995; Prescott, 1998; SAEM, 2000). In most companies, these leaders are usually composed of the executive team and they perform an essential role in the implementation of the company's vision and strategy. The ability of the top management structure to translate the vision and strategy into achievable milestones for the rest of the business requires a combination of a positive 'can do' mindset and knowledge on how to steer its people towards reaching them (Cowen \& Osborne, 2002; Nasser \& Vivier, 1995; Prescott, 1998). Beamish et al. (1997, cited in Eygelaar, 2004, p. 7) postulate:

That it is clear that the international manager and leader have to master new concepts and theories, cultivate new insights, command new skills, and above all, develop a global mindset conducive to global thinking and strategising beyond that which has been successful in the past. 
This integrated model proposes that vision and strategy are the first set of dimensions to the organisation within its 'direction' category. Strong leadership as discussed above appears as the second set of dimensions to this category (Cowen \& Osborne, 2002; Nasser \& Vivier, 1995; Prescott, 1998; SAEM, 2000).

\section{Delivery System}

The delivery system as proposed by Prinsloo et al. (1999) largely contains most of the fundamental activities to ensure that the company's strategic intent is achieved. The organisational, team and individual capabilities form part of the next set of dimensions that support the delivery system of the business. A considerable amount of emphasis is placed on the capabilities of the organisation at different levels to ensure that the organisation is able to achieve its objectives (Kaplan \& Norton, 1996; Prescott, 1998). Notwithstanding that today organisations operate within a global economy and these capabilities will also have to align themselves to what Marquardt (1999, p. 85) aptly coined as "global competencies". On the organisational level, the organisation is measured against its ability to provide the necessary organisational climate to foster a positive working environment for employees across all levels within the company (Cowen \& Osborne, 2002). At a team level, the organisation is assessed on how well it has implemented an effective strategy to enhance the performance of individual teams or departments. Further assessment of this capability takes place at an individual level where the employee assesses the organisation in terms of its ability to upskill employees, provide an empowering environment to perform and to allow whether it has succeeded in meeting the expectations of the employee (Cowen \& Osborne, 2002; Kaplan \& Norton, 1996; Nasser \& Vivier, 1995; Prescott, 1998; SAEM, 2000).

The effective management of resources, policies and procedures and performance and reward are parcelled in this system. This is done through the effective management of processes, ensuring that precise performance measures are in place as well as recognising and rewarding employees' for good performance or when they excel (Cowen \& Osborne, 2002; Nasser \& Vivier, 1995; SAEM, 2000).

\section{Business Results}

The organisation's yard stick for success, its 'business results', is a combination of stakeholder satisfaction and financial performance. The emphasis on financial performance measures on business results is unequivocally a vital element to all the excellence models. However, there is an ever-increasing suggestion that the importance of non-financial indicators (intangibles) cannot be avoided from the evaluation of the organisation's final business review. These indicators include incorporating the measurement of customer satisfaction, employee satisfaction and community satisfaction to the final balance sheet (Kaplan \& Norton, 1996; Prescott, 1998; Prinsloo et al., 1999; SAEM, 2000).

Finally, the integrated model applied in the South African context cannot ignore the importance of the partnering relationships between the various stakeholders already mentioned including organised labour and government (Prinsloo et al., 1999). This concept of joint governance or 'organisational governance' should not be forgotten as it performs a key role in the link between the delivery system and business results.

The complete integrated model is presented in Figure 2 below:

\section{Purpose of the study}

The first objective of this study is to develop an integrated theoretical model of a high performance organisational culture based on existing theoretical frameworks, models and concepts related to performance excellence. The second objective of the study is to develop a measuring instrument based on the said integrated theoretical model for assessing such a high performance culture.

\section{RESEARCH DESIGN}

\section{Research approach}

The research approach which was adopted for this study was based on the principles of the empirical-analytical paradigm. A cross-sectional survey design was applied to the study where a sample of the population was used. The information gathered from the sample was used to describe the population at that time (Kerlinger \& Lee, 2000). The survey technique as a method of data collection was used to gather information from the sample population using questionnaires (Burns \& Grove, 1993). The information generated from the assessment was used for deductive purposes (quantitative).

\section{Research methodology}

The research context

The participants identified for this study were employees of an organisation within the Fast Moving Consumer Goods (FMCG)

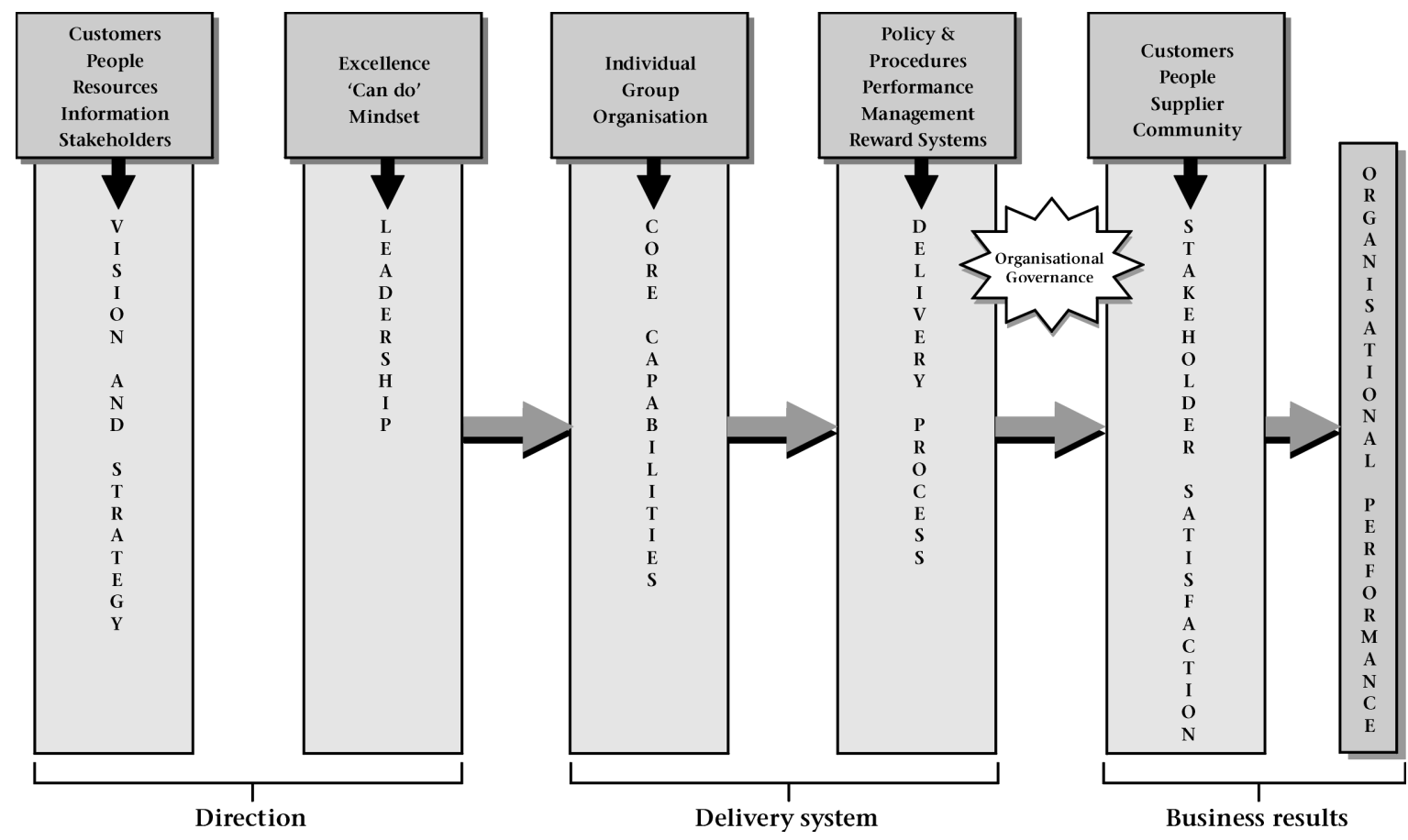

Figure 2: An integrated high performance organisational culture model 
industry in South Africa. The organisation was seen to be the market leader in its industry based on its reported financial and economic value-add indicators. At the time of the study, the organisation had de-listed from the stock exchange as a result of a merger with a leading beverage manufacturer. The organisation was still operating largely as before with minimal structural changes. The core business of the organisation is to manufacture, sell and distribute a world-brand soft drink and its related products.

\section{Participants}

As indicated, the participants used in the study were employees of a leading international beverage manufacturer, more specifically, its soft drinks division. At the time of administering the questionnaire, the division had a permanent complement of approximately 3500 employees based throughout South Africa that constituted the target population of the study. In view of the time constraints and the logistics of administering a questionnaire to the total target population, a non-random, proportionally stratified sampling strategy was adopted. The sampling frame was identified as all the 600 employees in different functions and levels of the business that had access to electronic communication (e-mail). The final number of completed questionnaires returned was 313 (a 52\% response rate).

An overview of the biographical details of the respondents is presented in Table 1 below.

TABLE 1

RESPONDENTS' BIOGRAPHICAL DETAILS

\begin{tabular}{|c|c|c|}
\hline Biographical variable & Number & Percentage \\
\hline \multicolumn{3}{|l|}{ GENDER } \\
\hline Male & 180 & $57,5 \%$ \\
\hline Female & 132 & $42,2 \%$ \\
\hline Total & 312 & $99,7 \%$ \\
\hline Missing & 1 & $0,3 \%$ \\
\hline Total & 313 & $100,0 \%$ \\
\hline \multicolumn{3}{|l|}{ AGE } \\
\hline $18-24$ & 11 & $3,5 \%$ \\
\hline $25-30$ & 78 & $24,9 \%$ \\
\hline $31-34$ & 69 & $22,0 \%$ \\
\hline $35-40$ & 63 & $20,1 \%$ \\
\hline $41-50$ & 64 & $20,4 \%$ \\
\hline $51->60$ & 19 & $6,1 \%$ \\
\hline Total & 304 & $97,1 \%$ \\
\hline Missing & 9 & $2,9 \%$ \\
\hline Total & 313 & $100,0 \%$ \\
\hline \multicolumn{3}{|l|}{ LEVEL IN ORGANISATION } \\
\hline Top Management & 14 & $4,5 \%$ \\
\hline Middle Management/Specialist Staff & 140 & $44,7 \%$ \\
\hline Supervisory/Team Leaders & 103 & $32,9 \%$ \\
\hline General Staff & 55 & $17,6 \%$ \\
\hline Total & 312 & $99,7 \%$ \\
\hline Missing & 1 & $0,3 \%$ \\
\hline Total & 313 & $100,0 \%$ \\
\hline
\end{tabular}

Of the responses received, the biographical data indicated that $57,5 \%$ of the respondents were male while $42,2 \%$ of the respondents were female. The percentage of female responses was relatively high in relation to the female/male ratio in the organisation of 1:5. The majority of responses received in the age group category were from respondents between 25 and 50 years old. The cumulative percentage for the four groups between these ages was $87,5 \%$. A smaller percentage of $3,5 \%$ and $6,1 \%$ respectively were experienced at the top and bottom ends of the age scale. Although not a perfect normal distribution curve, the age profile does conform to the principles of a normal distribution. It was noted that most of the responses were received from the groups categorised as either middle management or supervisory/team leaders, a response rate of $44,7 \%$ and $32,9 \%$ reported for each category respectively. The response rate from top management and general staff was comparatively low.

\section{Measuring instruments}

The measuring instrument specifically designed for this study by the first author was titled the High Performance Culture Questionnaire designed to measure various dimensions of the integrated organisational excellence model purported previously in the article. The author was unable to source any other comparative questionnaires used in an organisational context to assess a high performance culture as described by an integrated organisational excellence model.

The questionnaire consisted of the following 12 dimensions as depicted in the model namely:

- Dimension 1: Vision and Strategy (Sample item)

\begin{tabular}{|l|l|l|l|l|l|}
\hline $\begin{array}{l}\text { How optimistic are you } \\
\text { about management plans } \\
\text { for the future? }\end{array}$ & $\begin{array}{l}\text { 1. Very } \\
\text { pessimistic }\end{array}$ & 2. & 3. & 4. & $\begin{array}{l}5 . \text { Very } \\
\text { optimistic }\end{array}$ \\
- Dimension 2: Leadership \\
$\quad$ Sample item)
\end{tabular}
\begin{tabular}{|l|l|l|l|l|l|}
\hline $\begin{array}{l}\text { How open is your immediate } \\
\text { manager to new ideas? }\end{array}$ & $\begin{array}{l}1 . \text { Not open } \\
\text { at all }\end{array}$ & 2. & 3. & 4. & 5 Very open \\
\hline
\end{tabular}

- Dimension 3: Core Capability: Organisation (Sample item)

\begin{tabular}{|l|l|l|l|l|l|}
\hline $\begin{array}{l}\text { How important is respecting } \\
\text { diversity in your } \\
\text { organisation? }\end{array}$ & $\begin{array}{l}\text { 1. Not } \\
\text { important } \\
\text { at all }\end{array}$ & 2. & 3. & 4. & $\begin{array}{l}5 . \text { Very } \\
\text { important }\end{array}$ \\
\hline
\end{tabular}

- Dimension 4: Core Capability: Group/Team (Sample item)

\begin{tabular}{|l|l|l|l|l|l|}
\hline $\begin{array}{l}\text { How well does your team } \\
\text { understand their goals? }\end{array}$ & $\begin{array}{l}\text { 1. No } \\
\text { understand- } \\
\text { ing }\end{array}$ & 2. & 3. & 4. & $\begin{array}{l}5 . \text { Very good } \\
\text { understand- } \\
\text { ing }\end{array}$ \\
\hline
\end{tabular}

- Dimension 5: Core Competency: Individual (Sample item)

\begin{tabular}{|l|l|l|l|l|l|}
\hline $\begin{array}{l}\text { How empowered are you to } \\
\text { take control of your own } \\
\text { development within your } \\
\text { organisation? }\end{array}$ & $\begin{array}{l}1 . \text { Not } \\
\text { empowered }\end{array}$ & 2. & 3. & 4. & $\begin{array}{l}\text { 5. Highly } \\
\text { empowered }\end{array}$ \\
\hline
\end{tabular}

- Dimension 6: Reward System (Sample item)

\begin{tabular}{|l|l|l|l|l|l|}
\hline $\begin{array}{l}\text { How often are people, in } \\
\text { your organisation, who } \\
\text { perform well, rewarded } \\
\text { accordingly? }\end{array}$ & 1. Never & 2. & 3. & 4. & 5. Always \\
\hline
\end{tabular}

- Dimension 7: Performance Management (Sample item)

\begin{tabular}{|l|l|l|l|l|l|}
\hline $\begin{array}{l}\text { How often, in the last six } \\
\text { months, has your career } \\
\text { path in the organisation } \\
\text { been discussed? }\end{array}$ & 1. Not at all & 2. & 3. & 4. & $\begin{array}{l}5 . \text { Consis- } \\
\text { tently }\end{array}$ \\
\hline
\end{tabular}

- Dimension 8: Policies and Procedures (Sample item)

\begin{tabular}{|l|l|l|l|l|l|}
\hline $\begin{array}{l}\text { How well do you understand } \\
\text { the company's ethics policy? }\end{array}$ & $\begin{array}{l}1 . \text { Don't } \\
\text { understand } \\
\text { at all }\end{array}$ & 2. & 3. & 4. & $\begin{array}{l}5 . \text { Under- } \\
\text { stand very } \\
\text { well }\end{array}$ \\
\hline
\end{tabular}


- Dimension 9: Stakeholder Satisfaction: Customer (Sample item)

\begin{tabular}{|l|l|l|l|l|l|}
\hline $\begin{array}{l}\text { How much value does your } \\
\text { organisation place on } \\
\text { customer feedback? }\end{array}$ & 1. No value & 2. & 3. & 4. & 5. High value \\
\hline
\end{tabular}

- Dimension 10: Stakeholder Satisfaction: Supplier (Sample item)

\begin{tabular}{|l|l|l|l|l|l|}
\hline $\begin{array}{l}\text { To what extent has your } \\
\text { organisation refrained from } \\
\text { abusing its power/position } \\
\text { towards its suppliers? }\end{array}$ & $\begin{array}{l}\text { 1. Has not } \\
\text { refrained }\end{array}$ & 2. & 3. & 4. & $\begin{array}{l}\text { 5. Totally } \\
\text { refrained }\end{array}$ \\
\hline
\end{tabular}

- Dimension11: Stakeholder Satisfaction: Community (Sample item)

\begin{tabular}{|l|l|l|l|l|l|}
\hline $\begin{array}{l}\text { To what extent does your } \\
\text { organisation act in a } \\
\text { socially responsible way/ } \\
\text { manner? }\end{array}$ & $\begin{array}{l}1 . \text { Not } \\
\text { evident }\end{array}$ & 2. & 3. & 4. & $\begin{array}{l}\text { 5.Highly } \\
\text { evident }\end{array}$ \\
\hline
\end{tabular}

- Dimension 12: Stakeholder Satisfaction: People (Sample item)

\begin{tabular}{|l|l|l|l|l|l|}
\hline $\begin{array}{l}\text { To what extent has your } \\
\text { company established a } \\
\text { good relationship with } \\
\text { employees? }\end{array}$ & $\begin{array}{l}1 . \text { Very } \\
\text { poor }\end{array}$ & 2. & 3. & 4. & 5. Very good \\
\hline
\end{tabular}

On average, there were six items assigned to each theoretical dimension and they were all stated in a question format. The response scales were designed as five-point intensity scales where the lowest rating of 'one' signified a low preference by the respondent while a rating of 'five' signified a high preference by the respondent. Only the extreme poles of the response scales were anchored by defined categories.

\section{Research procedure}

The questionnaire was distributed to a pilot sample first. The feedback obtained from the pilot sample was used to improve the instrument for the final survey.

Top management of both the beverage manufacturer as well as the soft drinks division were approached and briefed on the purpose of the study. Permission was granted by the managing director of the soft drinks division to conduct the study with its employees with the condition that the first author would ensure that minimal disruption was created in the business and it was agreed that the questionnaires would be circulated electronically in the business.

The questionnaires were distributed to all the employees within the soft drinks division who had access to e-mail. The existing e-mail distribution lists were utilised for this purpose. All the participants were briefed on the purpose of the questionnaire and voluntary responses were solicited. The author emphasised to respondents that strict confidential handling of the questionnaires would be maintained and this was achieved by respondents replying to the author directly or the option to return a hardcopy of the completed questionnaire anonymously to the author was also made available to them. The author made an observation that approximately two thirds of the questionnaires were returned electronically. The first author was the only person involved in the administration of the questionnaire at all times during the data collecting period. The questionnaires were collected over a period of three weeks.

Although approximately two thirds of the questionnaires had been received electronically, all the questionnaires were presented to the statistical consultation service in hardcopy. This was a further control implemented to ensure anonymity.
Statistical analysis

The data from the questionnaires were collated and results analysed by the Statistical Consultation Service of the University of Johannesburg.

\section{RESULTS}

The statistical analyses to assess the validity and reliability of the instrument were conducted by using factor analyses on two levels followed by iterative item analyses. The main objective of factor analysis was to indicate whether variables measure similar dimensions and how much they do so (Kerlinger \& Lee, 2000). The suitability of each intercorrelation matrix for factor analysis was determined by utilising the Kaiser-Meyer-Olkin (KMO) Measure of Sampling Adequacy (MSA) and Bartlett's test of sphericity.

The Bartlett's test of sphericity tested the null hypothesis that states that the variables in the correlation matrix are not related. Thus, if the value of the test increases and the associated significance level decreases, there is a strong indication that the null hypothesis will be rejected and the alternative hypothesis accepted (Zillmer \& Vuz, 1995 as quoted in Potgieter \& Roodt, 2004). Similarly, if the value decreases and the significance level increases, the alternative hypothesis would be rejected and the null hypothesis accepted.

\section{First level factor analyses}

Owing to the unfavourable required item - respondent ratio $(1:>10)$ a slightly different procedure for the factor analyses was followed. The Kaiser-Meyer-Olkin MSA and Bartlett's test of sphericity values on each of the 12 item intercorrelation matrices of the theoretical dimensions are reported in Table 2. Based on the obtained high item intercorrelations for each dimension; all these values exceed the required levels, hence all 12 item intercorrelation matrices are suitable for second level factor analyses.

TABLE 2

KAISER-MEYER-OLKIN MSA, BARTLETT'S TEST FOR SPHERICITY AND Cronbach Alphas as per theoretical dimension

\begin{tabular}{|c|c|c|c|c|c|c|}
\hline $\begin{array}{l}\text { Theoretical } \\
\text { Dimension }\end{array}$ & Items & $\begin{array}{c}\text { Kaiser- } \\
\text { Meyer- } \\
\text { Olkin } \\
\text { MSA }\end{array}$ & $\mathrm{X}^{2}$ & $\begin{array}{l}\text { rtlet } \\
\text { Test }\end{array}$ & Sig & $\begin{array}{c}\text { Cronbach } \\
\text { Alphas }\end{array}$ \\
\hline Vision and Strategy & 6 & 0,883 & 919,085 & 15 & 0,000 & 0,887 \\
\hline Leadership & 7 & 0,857 & 1019,694 & 21 & 0,000 & 0,870 \\
\hline $\begin{array}{l}\text { Core Capability: } \\
\text { Organisation }\end{array}$ & 7 & 0,883 & 818,304 & 21 & 0,000 & 0,860 \\
\hline $\begin{array}{l}\text { Core Capability: } \\
\text { Group/Team }\end{array}$ & 7 & 0,863 & 1204,529 & 21 & 0,000 & 0,899 \\
\hline $\begin{array}{l}\text { Core Competency: } \\
\text { Individual }\end{array}$ & 9 & 0,862 & 937,808 & 36 & 0,000 & 0,848 \\
\hline Reward System & 5 & 0,767 & 757,487 & 10 & 0,000 & 0,850 \\
\hline $\begin{array}{l}\text { Performance } \\
\text { Management }\end{array}$ & 7 & 0,899 & 1015,889 & 21 & 0,000 & 0,891 \\
\hline Policies and Procedures & 6 & 0,858 & 669,079 & 15 & 0,000 & 0,847 \\
\hline $\begin{array}{l}\text { Stakeholder Satisfaction: } \\
\text { Customer }\end{array}$ & : 5 & 0,803 & 588,490 & 10 & 0,000 & 0,823 \\
\hline $\begin{array}{l}\text { Stakeholder Satisfaction: } \\
\text { Supplier }\end{array}$ & : 4 & 0,808 & 595,490 & 6 & 0,000 & 0,876 \\
\hline $\begin{array}{l}\text { Stakeholder Satisfaction: } \\
\text { Community }\end{array}$ & : 3 & 0,699 & 503,833 & 3 & 0,000 & 0,862 \\
\hline $\begin{array}{l}\text { Stakeholder Satisfaction: } \\
\text { People }\end{array}$ & : 11 & 0,896 & 1741,060 & 55 & 0,000 & 0,896 \\
\hline
\end{tabular}


TABle 3

INTERCORRELATION OF THE THEORETICAL DIMENSIONS $(12 \times 12)$

\begin{tabular}{|c|c|c|c|c|c|c|c|c|c|c|c|c|c|}
\hline Dimension & & 1 & 2 & 3 & 4 & 5 & 6 & 7 & 8 & 9 & 10 & 11 & 12 \\
\hline \multirow{3}{*}{$\begin{array}{l}1 \text { Vision and } \\
\text { Strategy }\end{array}$} & Pearson & 1 & 0,756 * * & $0,755^{\text {* * }}$ & 0,691 * * & 0,659 ** & 0,665 ** & 0,638 * * & 0,654 * * & 0,568 * * & $0,558^{* *}$ & 0,577 * * & 0,719 * * \\
\hline & $\begin{array}{l}\text { Correlation } \\
\mathrm{N}\end{array}$ & 296 & 286 & 284 & 283 & 276 & 280 & 269 & 280 & 286 & 273 & 287 & 271 \\
\hline & & 20 & 200 & 204 & 203 & 210 & 200 & 209 & 200 & 200 & 270 & $20 \%$ & 271 \\
\hline \multirow[t]{2}{*}{2 Leadership } & $\begin{array}{l}\text { Pearson } \\
\text { Correlation }\end{array}$ & $0,756^{* *}$ & 1 & $0,776^{* *}$ & 0,771 * * & 0,735 * * & 0,689 * * & 0,690 ** & 0,650 ** & 0,525 ** & $0,519^{* *}$ & $0,602 * *$ & 0,741 ** \\
\hline & $\mathrm{N}$ & 286 & 299 & 289 & 290 & 282 & 282 & 274 & 284 & 290 & 276 & 291 & 274 \\
\hline 3 Core & Pearson & $0,755^{* *}$ & $0,776^{* *}$ & 1 & 0,758 * * & 0,687 * * & 0,701 * * & 0,615 * * & 0,710 * * & 0,568 ** & 0,535 * * & $0,615^{* *}$ & 0,763 * * \\
\hline Capability: & Correlation & & & & & & & & & & & & \\
\hline Organisation & $\mathrm{N}$ & 284 & 289 & 296 & 287 & 278 & 278 & 271 & 281 & 288 & 276 & 289 & 275 \\
\hline 4 Core & Pearson & 0,691 * * & 0,771 * * & $0,758^{* *}$ & 1 & 0,712 ** & 0,661 * * & 0,704 * * & $0,673 * *$ & $0,527 *$ * & 0,483 * * & 0,537 * * & 0,711 * * \\
\hline Capability: & Correlation & & & & & & & & & & & & \\
\hline Group/Team & $\mathrm{N}$ & 283 & 290 & 287 & 297 & 280 & 281 & 272 & 284 & 290 & 276 & 291 & 274 \\
\hline 5 Core & Pearson & 0,659 * * & 0,725 ** & 0,687 * * & 0,712 * * & 1 & $0,578 * *$ & 0,652 ** & $0,669 * *$ & 0,591 * * & 0,525 * * & 0,577 * * & 0,727 * * \\
\hline Competency: & Correlation & & & & & & & & & & & & \\
\hline Individual & $\mathrm{N}$ & 276 & 282 & 278 & 280 & 290 & 273 & 265 & 274 & 280 & 266 & 283 & 268 \\
\hline \multirow[t]{2}{*}{6 Reward System } & $\begin{array}{l}\text { Pearson } \\
\text { Correlation }\end{array}$ & $0,665^{* *}$ & 0,689 * * & 0,701 * * & 0,661 * * & 0,578 ** & 1 & 0,717 * * & 0,633 * * & $0,426^{* *}$ & 0,459 * * & 0,521 ** & 0,697 * * \\
\hline & $\mathrm{N}$ & 280 & 282 & 278 & 281 & 273 & 291 & 269 & 279 & 283 & 273 & 285 & 269 \\
\hline \multirow{2}{*}{$\begin{array}{l}7 \text { Performance } \\
\text { Management }\end{array}$} & Pearson & $0,683^{* *}$ & 0,690 ** & $0,615^{* *}$ & 0,704 * * & 0,652 ** & $0,717^{* *}$ & 1 & 0,627 * * & 0,405 ** & $0,410^{* *}$ & 0,482 ** & 0,652 ** \\
\hline & $\begin{array}{l}\text { Correlation } \\
\mathrm{N}\end{array}$ & 269 & 274 & 271 & 272 & 265 & 269 & 282 & 276 & 276 & 263 & 277 & 266 \\
\hline \multirow{3}{*}{$\begin{array}{l}8 \text { Policies and } \\
\text { Procedures }\end{array}$} & Pearson & $0,654^{* *}$ & 0,650 ** & $0,710^{* *}$ & 0,673 * * & 0,669 ** & 0,633 * * & 0,627 * * & 1 & 0,590 ** & $0,566 * *$ & 0,627 * * & $0,706^{* *}$ \\
\hline & $\begin{array}{l}\text { Correlation } \\
\mathrm{N}\end{array}$ & 280 & 284 & 281 & 284 & 274 & 278 & 276 & 294 & 288 & 27 & 288 & 272 \\
\hline & & & & & & & & & & & & & \\
\hline \multirow{3}{*}{$\begin{array}{l}9 \text { Stakeholder } \\
\text { Satisfaction: } \\
\text { Customer }\end{array}$} & Pearson & 0,568 * * & 0,525 * * & 0,568 * * & 0,527 * * & 0,591 * * & 0,426 * * & 0,405 * * & 0,590 ** & 1 & 0,683 * * & 0,580 ** & $0,586^{* *}$ \\
\hline & Correlation & & & & & & & & & & & & \\
\hline & $\mathrm{N}$ & 286 & 290 & 288 & 290 & 280 & 283 & 276 & 288 & 300 & 280 & 294 & 278 \\
\hline \multirow{3}{*}{$\begin{array}{l}10 \text { Stakeholder } \\
\text { Satisfaction: } \\
\text { Supplier }\end{array}$} & Pearson & 0,558 ** & 0,519 * * & 0,535 ** & 0,483 * * & $0,525^{* *}$ & 0,459 * * & 0,410 * * & $0,566^{* *}$ & $0,683^{* *}$ & 1 & $0,576^{* *}$ & $0,615^{* *}$ \\
\hline & Correlation & & & & & & & & & & & & \\
\hline & $\mathrm{N}$ & 273 & 276 & 276 & 276 & 266 & 273 & 263 & 273 & 280 & 285 & 283 & 267 \\
\hline \multirow{3}{*}{$\begin{array}{l}11 \text { Stakeholder } \\
\text { Satisfaction: } \\
\text { Community }\end{array}$} & Pearson & 0,577 * * & 0,602 ** & $0,615^{* *}$ & 0,537 * * & 0,577 * * & 0,521 * * & 0,482 ** & 0,627 * * & 0,580 ** & $0,576^{* *}$ & 1 & $0,676^{* *}$ \\
\hline & Correlation & & & & & & & & & & & & \\
\hline & $\mathrm{N}$ & 287 & 291 & 289 & 291 & 283 & 285 & 277 & 288 & 294 & 283 & 302 & 278 \\
\hline \multirow{3}{*}{$\begin{array}{l}12 \text { Stakeholder } \\
\text { Satisfaction: } \\
\text { People }\end{array}$} & Pearson & 0,719 ** & 0,741 * * & 0,763 * * & 0,711 * * & 0,727 * * & 0,697 * * & 0,650 * * & $0,706^{* *}$ & $0,586^{* *}$ & $0,615^{*}$ * & $0,676^{*}$ * & 1 \\
\hline & Correlation & & & & & & & & & & & & \\
\hline & $\mathrm{N}$ & 271 & 274 & 275 & 274 & 268 & 269 & 266 & 272 & 278 & 267 & 278 & 283 \\
\hline
\end{tabular}

** Correlations are significant at the 0,01 level (2-tailed)

The intercorrelation matrix of the dimension scores is presented in Table 3. The Cronbach Alphas produced from the iterative item analyses were on acceptable levels indicating high internal consistency levels, thus suggesting a similar underlying construct for each of the 12 theoretical dimensions. Sub-scores were subsequently calculated for each of these 12 dimensions and these scores were then intercorrelated. The correlations ranged from 0,405 and 0,776 indicating that all the dimensions share some common variance.

TABLE 4

KAISER-MEYER-OLKIN MSA,BARTLETT'S TEST FOR SPHERICITY OF THE UNREDUCED SUBSCORE INTERCORRELATION MATRIX OF THEORETICAL DIMENSIONS

\begin{tabular}{llc}
\hline Kaiser-Meyer-Olkin MSA & & 0,946 \\
\hline Bartlett's Test of Sphericity & Approx. Chi-Square & 1932,980 \\
& df & 66 \\
& Sig. & 0,000 \\
\hline
\end{tabular}

Second level factor analysis

The Kaiser-Meyer-Olkin MSA and Bartlett's test of sphericity were also applied to the sub-score intercorrelation matrix to test its suitability for factor analysis. The results generated are represented in Table 4 and it indicates that the matrix is suitable for the second level factor analysis.

Eigenvalues were calculated on the unreduced sub-score intercorrelation matrix and a single factor was postulated. The eigenvalues are presented in Table 5.

A single factor was extracted using Principal Axis factoring and four iterations were required for the solution to converge. The dimensions in comparison to the single factor showed high loadings and varied from between 0,878 to 0,641 . Table 7 reflects these details.

An acceptable overall Cronbach Alpha of 0,947 signified that the instrument has a high internal consistency. Refer to table 7 for the reliability statistics of the scale.

Additional statistical analysis included the use of ANOVAs to ascertain if there were any significant differences found in 
respect of the mean scores for gender, age groups and job levels in the organisation. No significant statistical differences were found between the overall mean scores for these categories and these results would thus not be reported here. The lack of significant differences indicates that the instrument possibly exhibits a lack of differential validity.

TABLE 5

EIGENVALUES OF THE UNREDUCED SUBSCORE INTERCORRELATION MATRIX OF THEORETICAL DIMENSIONS

\begin{tabular}{lccc}
\hline \multicolumn{3}{c}{ INITIAL EIGENVALUES } \\
\hline Factor & Total & \% of Variance & Cumulative \% \\
1 & 7,723 & 64,360 & 64,360 \\
2 & 1,017 & 8,478 & 72,838 \\
3 & 0,541 & 4,507 & 77,345 \\
4 & 0,450 & 3,754 & 81,099 \\
5 & 0,411 & 3,427 & 84,526 \\
6 & 0,383 & 3,189 & 87,715 \\
7 & 0,326 & 2,718 & 90,433 \\
8 & 0,298 & 2,486 & 92,919 \\
9 & 0,281 & 2,342 & 95,260 \\
10 & 0,217 & 1,809 & 97,070 \\
11 & 0,180 & 1,500 & 98,569 \\
12 & 0,172 & 1,431 & 100,000 \\
\hline
\end{tabular}

Extraction Method: Principal Axis Factoring

TABLE 6

UNROTATED FACTOR MATRIX OF THEORETICAL DIMENSIONS

\begin{tabular}{lcc}
\hline Theoretical Dimension & Factor 1 & Communalities \\
\hline Stakeholder Satisfaction: People & 0,878 & 0,771 \\
Core Capability: Organisation & 0,873 & 0,763 \\
Leadership & 0,855 & 0,731 \\
Core Capability: Group/Team & 0,825 & 0,680 \\
Vision and Strategy & 0,822 & 0,676 \\
Policies and Procedures & 0,814 & 0,662 \\
Core Competency: Individual & 0,807 & 0,651 \\
Reward System & 0,762 & 0,581 \\
Performance Management & 0,730 & 0,534 \\
Stakeholder Satisfaction: Community & 0,691 & 0,477 \\
Stakeholder Satisfaction: Customer & 0,650 & 0,422 \\
Stakeholder Satisfaction: Supplier & 0,641 & 0,411 \\
\hline
\end{tabular}

TABLE 7

RELIABILITY STATISTICS OF THE QUESTIONNAIRE

\begin{tabular}{lccc}
\hline Dimension & $\begin{array}{c}\text { Scale } \\
\text { Mean if } \\
\text { dimension } \\
\text { deleted }\end{array}$ & $\begin{array}{c}\text { Scale } \\
\text { Variance if } \\
\text { dimension } \\
\text { deleted }\end{array}$ & $\begin{array}{c}\text { Cronbach } \\
\text { Alpha if } \\
\text { dimension } \\
\text { deleted }\end{array}$ \\
\hline Vision and Strategy & 21,33 & 21,713 & 0,887 \\
Leadership & 26,40 & 29,289 & 0,870 \\
Core Capability: Organisation & 24,43 & 26,768 & 0,860 \\
Core Capability: Group/Team & 25,31 & 31,484 & 0,899 \\
Core Competency: Individual & 35,97 & 33,397 & 0,848 \\
Reward System & 15,45 & 19,807 & 0,850 \\
Performance Management & 25,33 & 36,650 & 0,891 \\
Policies and Procedures & 22,21 & 20,781 & 0,847 \\
Stakeholder Satisfaction: Customer & 18,99 & 13,140 & 0,823 \\
Stakeholder Satisfaction: Supplier & 13,49 & 10,997 & 0,876 \\
Stakeholder Satisfaction: Community & 11,40 & 7,079 & 0,862 \\
Stakeholder Satisfaction: People & 37,61 & 68,672 & 0,896 \\
\hline
\end{tabular}

Cronbach Alpha = 0,947

\section{DISCUSSION}

The preceding literature study of the article focussed on identifying the underlying theoretical dimensions for a high performance culture for the purpose of constructing an integrated theoretical model based on international as well as South African models (Marquardt, 1999; Nasser \& Vivier, 1995; Prescott, 1998; Prinsloo et al., 1999; Rhinesmith, 1996; Robson, 1988; SAEM, 2000). The 12 dimensions that were extrapolated were based on the authors' interpretation of what a high performance organisational culture would consist of. The model was the foundation for the development of a high performance culture questionnaire.

The empirical study focused on the results of the factor analyses that were conducted on two levels as well as on the iterative item analyses of this questionnaire. The first level factor analyses on each of the 12 theoretical dimensions revealed high item intercorrelations (confirmed by the Bartlett's tests of sphericity) and high levels of internal consistency (reflected by Cronbach Alphas in excess of 0,82 ) for all 12 dimensions. These findings indicated that the items for each dimension were measuring the same underlying 'construct'.

A second level factor analysis was conducted on a subscore intercorrelation matrix of the 12 dimensions and a single factor was extracted. This suggested that the questionnaire reliably measured a single construct which in the context of this study could be High Performance Culture. This may be a controversial observation (but one worth further investigation) since the initial thinking around culture was that it was difficult to be precisely defined. The overall reliability coefficient for the scale was 0,947 . This denoted that the questionnaire or measuring instrument could reliably be used in similar organisations or settings. It should, however, be tested further in different contexts or settings.

Based on this said analyses, the instrument is said to have both face and content validity. Face validity refers to the fact that the instrument appears to measure what it is supposed to measure for each theoretical dimension (Kerlinger \& Lee, 2000), while content validity refers to the coverage of the content domain of the theoretical construct (Kerlinger \& Lee, 2000), in this case the 12 theoretical dimensions of the model of a high performance culture. The content validity is further supported by the convergent validity of the instrument, based on the relative high intercorrelations of the 12 theoretical dimensions (Kerlinger \& Lee, 2000). There was no indication that any of the dimensions were unrelated or that they diverged from one another.

As stated, the first objective of the study was to develop an integrated theoretical model of a high performance organisational culture and the second objective was to develop a measuring instrument based on the integrated model for assessing a high performance organisational culture. The obtained results indicate that the objectives of this study were met. The dimensions identified in the integrated high performance organisational culture model were significantly correlated and point towards a uni-dimensional construct as proposed by the theoretical model. This suggests that the questionnaire can be reliably used within organisations to assess the dimensions of high performance culture in relation to the proposed model.

Practical implications of the study

Organisations can no longer measure their level of success based entirely on a single bottom line of financial success. An organisation that proposes to adopt a model of excellence based on this premise will only be experiencing short term gains (Darling, 1999; Zhao, 2004). The challenge for any company playing in the global market is to ensure the establishment of a longer time horizon. 
So the question that arises for organisations today is - "what are the key areas of focus in our business that will ensure sustainability into the future?" Part of the answer lies in developing an organisation with a high performance culture.

In order to identify what the specific areas of focus should be, organisations could use the questionnaire designed in this study as a self-assessment tool to assist with identifying areas of strength as well as areas for improvement. The information could in turn assist with enhancing strategic business plans or even assist with the design of new strategies for the business (Samuelsson \& Nilsson, 2002; SAEM, 2000).

On a practical level, the questionnaire is relatively uncomplicated and can easily be administered within organisations across different levels and groups.

Limitations of the study

The limitations of the study were identified as follows:

- The questionnaire was only tested in one organisation.

- The use of the electronic communication system (e-mail) limited the number of responses from employees who did not have direct access to this facility at the organisation. A more representative sample of the lower levels in the organisation may have been obtained if hardcopies had been issued as well.

- The study was a cross-sectional design which only considered the organisation as it was in the given period of time. Due to the scope of the study, there was no opportunity to consider a longitudinal study but it may be a future research opportunity.

- The findings of the study were not specifically intended to make any generalisations of the organisation concerned or the industry in which it operates, but was focused on evaluating the instrument against the theoretical dimensions identified.

- The role of the learning organisation as a dimension of a high performance culture requires further exploration (compare Argyris, 1990; Senge, 1990).

- It appears as if the instrument may lack differential validity which is difficult to assess in a single organisational setting, but which could be evaluated again in future studies.

Despite these limitations, the purpose of this specific study was achieved. The outcome of the study points to the fact that the questionnaire is a valid and reliable measuring instrument which can be used by organisations to assess dimensions of the proposed high performance organisational culture model.

\section{Future research opportunities}

A suggestion for future research is to conduct a longitudinal study to assess whether organisations that choose to change the design of their business strategies with a view to improving their organisational excellence can be tracked for improvement on all or selected theoretical dimensions over time. This can be in the form of both a quantitative as well as a qualitative study.

Another suggestion for future research is to use the measuring instrument or questionnaire in a comparative study between two or more organisations to further test the statistical properties of the instrument and more specifically, its differential validity (compare Du Toit \& Roodt, 2003). The comparative study could also involve the comparison of the questionnaire with other measuring instruments in the industry that purports to test similar dimensions of high performance culture. A further opportunity exists for the research to be replicated.

\section{Value of the study}

The authors propose an integrated high performance organisational culture model of which the dimensions are based on the incorporation of elements of prominent international and local business excellence models. It is a theoretical model designed from selected schools of thought.
The incorporation of excellence models spoke to the element of performance excellence which has become increasingly important for organisations because they are competing on the global arena and they need to ensure their survival. Organisations use these models and awards as a way of comparing themselves against their counterparts and evaluating how well or badly they rank against them.

Customer centricity was another fundamental component of the model. Contemporary writers consistently allude to the ever rising status that customers are receiving in business. There was acceptance that high performing organisations were successful because they recognised that the customer is what business was all about (Neely,1999)

The theoretical model is multifaceted because high performance businesses are multifaceted. The results offered the opportunity for further studies to be conducted to assess high performance cultures and to assess whether high performance cultures could be compared to each other and if there are common attributes that could define their 'personalities'.

The measuring instrument designed for the purposes of assessing the model was found to exhibit sound statistical properties which meant that the questionnaire could be used by organisations as a diagnostic tool to assess their areas of strength and identify areas for improvement, a tool used for continuous evaluation and benchmarking against self and others - the organisation would be able to use the information to build or redesign its strategy to ensure future growth.

\section{Conclusion}

The objectives of the study were met based on the results that were generated from the research. The statistical analyses indicated that the measuring instrument is internally consistent. An integrated model of a high performance organisational culture was postulated and in turn tested. It should be noted that the differential validity of the instrument was not evident and it is identified as a factor to be considered in future research.

\section{REFERENCES}

Argyris, C. (1990). Overcoming Organizational Defenses: Facilitating Organizational Learning. Boston, MA: Allyn \& Bacon.

Bower, M. (1966). The will to manage. New York: McGraw-Hill.

Burns, N. \& Grove, S.K. (1993). The practice of nursing research: Conduct, critique and utilization ( $2^{\text {nd }}$ ed.). Philadelphia, PA: W.B. Saunders.

Clemmer, J. (n.d.). Building a High Performance Culture. Retrieved 1 October 2005, from the World Wide Web on www.clemmer.net/speaking/bhpc_wk.shtml.

Cowen, S.S. \& Osborne, R.L. (2002). High-performance companies: the distinguishing profile. Management Decision, 40 (3), 227-231.

Dahlgaard, J.J., Kristensen, K. \& Kanji, G.K. (1998). Fundamentals of Total Quality Management, London: Chapman \& Hall.

Darling, J.R. (1999). Organization excellence and leadership strategies: Principles followed by top multinational executives. Leadership and Organization Development Journal, 20 (6), 309-321.

Deal, T. \& Kennedy, A. (1982). A corporate culture. Reading, MA: Addison-Wesley.

Du Toit, W. \& Roodt, G. (2003). The discriminant validity of the Culture Assessment Instrument: A comparison of company cultures. SA Journal of Human Resources Management, 1 (1), 77-84

Eskildsen, J.K., Kristensen, \& K. \& Juhl, H.J. (2001). The criterion weights of the EFQM excellence model. The International Journal of Quality \& Reliability Management, 18 (8/9), 783-795. 
Evans, J.R. \& Jack,E.P. (2003). Validating key results linkages in the Baldridge Performance Excellence Model. The Quality Management Journal, 10 (2), 7-18.

Eygelaar, S.J.D. (2004). The application of the excellence model to enhance military health service delivery and performance excellence. Published doctoral thesis. Rand Afrikaans University: Johannesburg, South Africa.

Eygelaar, S.J.D. \& Uys, J.S. (2004). The application of the excellence model to enhance health service delivery and performance excellence in a state department. SA Journal of Human Resource Management, 2 (3), 32-41.

Hansen, G. \& Wernerfelt, B. (1989). Determinants of firm performance: the relative impact of organizational and factors. Strategic Management Journal, 10 (3), 399-411.

Kaplan, R. S. (2005). How the balanced scorecard complements the McKinsey 7-S model. Strategy \& Leadership, 33 (3), 41-46.

Kaplan, R.S. \& Norton, D. (1996). The balanced scorecard: Translating strategy into action. Boston, MA: Harvard Business School Press.

Kerlinger, F.N. \& Lee, H.B. (2000). Foundations of Behavioural Research (4th ed.). Australia: Wadsworth Thomson Learning.

Kotter, J.P. \& Heskett, J.L. (1992). Corporate culture and performance. New York: The Free Press.

Lok, P. \& Crawford, J. (2004). The effect of organisational culture and leadership style on job satisfaction and organisational commitment. The Journal of Management Development, 23 (3/4), 321-338.

Marquardt, M.J. (1999). Global advantage - How world-class organisations improve performance through globilisation. Houston: Gulf Productions.

McLaughlin, T.A. (n.d). About Face: How to change organizational culture. The Non-profit Times. Retrieved 1 January 2002, from General Business File International.

McNamara, C. Organisational Culture. Retrieved on 26 April 2006, from the World Wide Web on www.managementhelp. org/org_thry/culture/culture.htm.

Nasser, M.E. \& Vivier, F.J. (1995). Mindset for New Generation Organisation: how leading South African companies create counter-trend performance despite turbulence. Kenwyn: Juta.

Neely, A. (1999). The performance measurement revolution: why now and what next? International Journal of Operations \& Production Management, 19 (2), 205.
Payne, R. \& Pugh, D.S. (1983). Organizational Structure and Climate. In M.D. Dunnette (Ed.), Handbook of Industrial and Organizational Psychology. New York: John Wiley and Sons.

Peters, T. \& Waterman, R. (1982). In search of excellence. New York: Harper and Row.

Petkoon, L. \& Roodt, G. (2004). The discriminant validity of the Culture Assessment Instrument: A comparison of company sub-cultures. SA Journal of Industrial Psychology, 30 (1), 74 82.

Potgieter, A. \& Roodt, G. (2004). Measuring a customer intimacy culture in a value discipline context. SA Journal of Human Resource Management, 2 (3), 25-31.

Prescott, B.D. (1998). Creating a world class organization. London: Kogan Page.

Prinsloo, K.J., Moropodi, J.N., Slabbert, J.A. \& Parker, A.J. (1999). A perspective on the world -class company. Pretoria: Strat-Excell Pty. Ltd.

Quinn, R.E. (1988). Beyond rational management. San Francisco: Jossey-Bass

Rhinesmith, S.H. (1996). A manager's guide to globilisation. Six skills for success in a changing world. ASTD: McGraw-Hill.

Robson, M. (1988). The journey to excellence. Wantage: M.R.A. International Ltd.

Samson, D. \& Challis, D. (1999). Partners of excellence: The new principles of corporate success. London: Prentice Hall.

Samuelsson, P. \& Nilsson, L-E. (2002). Self-assessment practices in large organisations: Experiences from using the EFQM model. The international Journal of Quality \& Reliability Management, 19 (1), 10-24.

Saol, S. (2000). Exploring Organisational Culture. Retrieved on 12 March 2006, from www.cdra.org.za/articles.

Schein, E. (1990). Organizational culture. American Psychologist, 4 (2), 109-119.

South African Excellence Model. (2000). General Guidelines for Public Service Performance Excellence Self-Assessment, No. 5.

White, J. (1991). Corporate Culture and Corporate Success. South African Handbook of Management Development, 6 (6): 17-22.

Zhao, F. (2004). Siemens' business excellence model and sustainable development. Measuring Business Excellence, 8 (2), 55-65.

Zillmer, E.A. \& Vuz, J.K. (1995). Factor analysis with Rorschach data. In J.E. Exner (Ed.) Issues and methods in Rorschach research. California: Sage Publications. 